\title{
Latitudinal variation in patterns of colonisation of cryptic calcareous marine organisms
}

\author{
N. J. Holmes*, V. J. Harriott, S. A. Banks \\ School of Resource Science and Management, Southern Cross University, PO Box 157, Lismore, \\ New South Wales 2480, Australia
}

\begin{abstract}
Few studies of fouling communities have directly compared colonisation patterns over wide geographical scales in similar community types. In this study, the recruitment and early growth of calcareous cryptic fouling organisms were examined on settlement panels at 2 tropical and 2 subtropical locations at varying distances from the mainland in eastern Australia. Species diversity and cover on the settlement panels after 6 mo were higher at the subtropical inshore site than at any of the offshore or tropical sites. Classification of the sites by multivariate cluster analysis and ordination showed clear distinctions between inshore and offshore sites, while sites separated by approximately $14^{\circ}$ of latitude were less clearly distinguished. Inshore/offshore vanation in the physical environment, especially turbidity and eutrophication, and the effects of longshore currents in the regions are possible explanations for these patterns. There was a significantly higher weight of calcified material at the subtropical inshore site than at the other 3 sites, attributable to higher cover of both bryozoans and barnacles; these taxa are likely to make a signuficant contribution to community calcification rates in subtropical coral communities. Competition for space with encrusting species is proposed as a potential mechanism limiting coral recruitment in coastal subtropical eastern Australıa.
\end{abstract}

KEY WORDS: Settlement - Epibiota - Calcification · Fouling communities

\section{INTRODUCTION}

Comparisons of species diversity and community ecology along latitudinal gradients have suffered from a lack of consistency in sampling methodology, and a paucity of studies comparing more than one site at each latitude (Schoener et al. 1978, Black \& Prince 1983, Crossland 1988, Keough 1988, McGuinness 1990, Clarke 1992). Most studies employing settlement panels to examine patterns of recruitment and succession in cryptic fouling communities have been restricted to a single geographical location (reviewed in Schoener 1982). Since a variety of panel sizes, panel deployment patterns and analytical techniques have been used by various workers, evaluation of regional variation in these communities may be confounded by methodological variation (Jackson 1977a, Schoener et al. 1978, Harris \& Irons 1982, Schoener 1982).

Habitat space for settlement of propagules is widely regarded as a limiting resource in many marine envi-

•E-mail: nholmes@scu.edu.au ronments (Dayton 1971, Jackson 1977a, Russ 1982, Connell \& Keough 1985, Keough 1988) and the patterns of space occupation in the early successional stages may play a major role in determining community structure (Sutherland 1974). Discussions of what has recently been termed 'supply side ecology' (e.g. Underwood \& Fairweather 1989) have re-emphasised the role of larval supply as a major factor in the development and maintenance of benthic communities (Keough 1988, Rodriguez et al. 1993). Studies of recruitment of propagules on fresh artificial settlement surfaces can show the range of sessile organisms that are available to settle, recruit and occupy space in the habitat (Schoener 1982). While artificial panels are unable to replicate the 3-dimensional structure of natural cryptic habitats (Ginsburg 1983, Gischler \& Ginsburg 1996), they appear to be an effective way of examining small-scale, short-term processes of recruitment, with the term 'recruitment' used here to include the processes leading to settlement and metamorphosis of larvae and their survival until observation (Keough \& Downes 1982, Rodriguez et al. 1993). 
Propagule availability at panel surfaces will be a function of several factors (Rodriguez et al. 1993), such as the location of breeding populations, the length of propagule life (Bingham 1992, Carlon \& Olson 1993), the period of settlement competence and the hydrodynamic processes supplying propagules to a habitat, including recirculation (Black 1988, Sammarco \& Andrews 1989. Sammarco et al. 1991) Biological influences such as predation of larvae may also operate in some circumstances (Young 1988) and the nature of the pre-existing biota (Benayahu \& Loya 1984, Patzkowsky 1988) is frequently significant. Allelopathic interactions between space-occupying biota such as crustose coralline algae, soft corals and ascidians may accelerate (Sebens 1983, Standing et al. 1984) or inhibit (Breitburg 1984, Standing et al. 1984) recruitment or growth of cryptic organisms.

Recent studies on coral reefs have examined the timing and extent of early recruitment of coral spat, using natural substrata (Rylaarsdam 1983, Wallace 1985, Carleton \& Sammarco 1987) and artificial settlement surfaces (van Moorsel 1988, Fisk \& Harriott 1990, Smith 1992) at a variety of locations across the continental shelf (Sammarco 1983, Fisk \& Harriott 1990) and at different latitudes (Harriott 1992. Harriott \& Banks 1995) During investigations of coral recruitment at several tropical and subtropical sites (Fisk \& Harriott 1990, Harriott 1992, Harriott \& Banks 1995) it was observed that there were large differences in the abundance of cryptic encrusting calcareous organisms between sites, giving the opportunity of defining, on a broad scale, the general latitudinal and inshore/offshore variation in the recruitment of encrusting species in these regions. Because of the influence of larval availability, settlement and survival, panel assemblages at particular sites are likely to reflect those of nearby cryptic habitats, which may vary latitudinally or along an onshoreoffshore gradient.

There are only a few similar studies of spatial variation in recruitment and abundance of other fouling taxa using consistent sampling techniques comparing latitudes (Schoener et al. 1978), or distance from the shore (Long \& Rucker 1970, Hughes \& Jackson 1992), but never both. The aims of this study are therefore to examine patterns in recruitment, species diversity, cover and calcification rates of cryptic calcareous taxa and to determine whether these vary spatially with latitude and distance from shore, and temporally with season.

\section{METHODS}

Ceramic tiles, approximately $15 \times 15 \mathrm{~cm}$, were used as settlement panels and were submerged as described in Fisk \& Harriott (1990) in about 6 to $9 \mathrm{~m}$ water depth and about 15 to $20 \mathrm{~cm}$ above the substratum. Panels were attached horizontally in pairs to steel racks with the unglazed tile surface downwards, for periods of 4 to 8 mo during winter (March to October approx.) and summer (October to March approx.). The sites (Fig 1) and seasons of submergence were: Cape Tribulation (16 $\left.05^{\prime} \mathrm{S}\right)$, winter 1987 and summer 1987-88; Green Island $\left(16^{\circ} 50^{\prime} \mathrm{S}\right)$, winter 1988 and summers of $1986-87$ and 1987-88; Solitary Islands (30 S), winter 1991 and summers of 1990-91 and 1991-92; and Lord Howe Island (31.33'S), winter 1991 and summers of 1990-91 and 1991-92. The panels used in this study were a subset $(7$ to 10 panels per site per time, comprising panels not damaged in storage) of those used at each locality by Fisk \& Harriott (1990), Harriott (1992) and Harriott \& Banks (1995) for studies on coral recruitment.

On the mainland fringing reefs at Cape Tribulation, the coral communities extend from the outer reef flat to

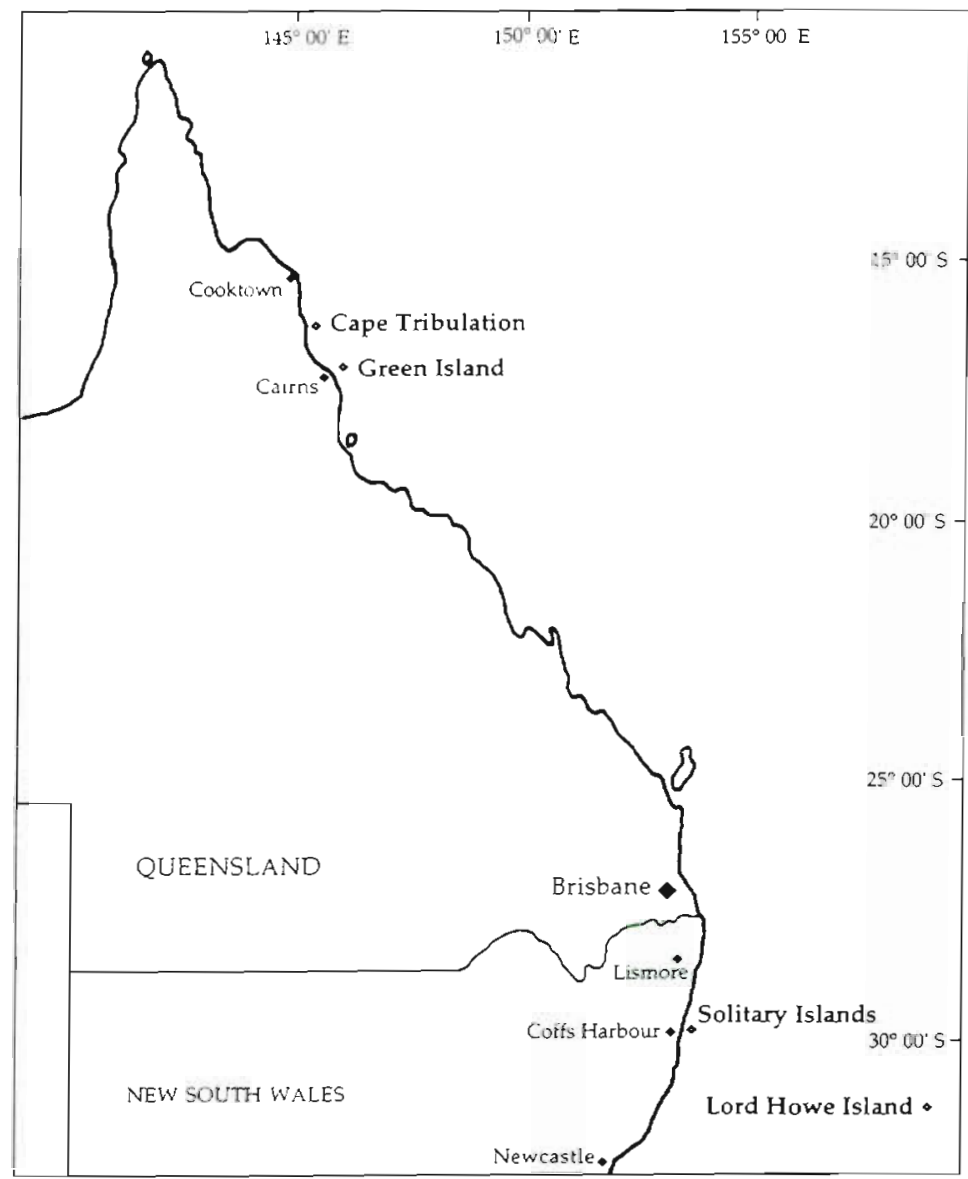

Fig. 1 Location of study sites on the east coast of Australia 
a depth of about $5 \mathrm{~m}$. They experience high turbidity and sedimentation rates, but have high coral cover of 33 to $63 \%$ (Ayling \& Ayling 1987). Settlement panels were located on the seaward slope of 6 fringing reefs. The reefs at Green Island, $13 \mathrm{~km}$ northeast of Cape Grafton, surround a vegetated sand cay and were greatly affected by Acanthaster planci during the outbreaks of the late 1960 s and early 1980 s (Fisk et al 1989). Racks were located on the forereef and backreef slopes and panels from both locations were analysed in this study.

At the Solitary Islands, racks were located about 10 to $20 \mathrm{~m}$ north and south of SW Solitary Island, in about $9 \mathrm{~m}$ water depth. The island is about $4 \mathrm{~km}$ from the mainland, and coral cover near the location of the northern panels was over $50 \%$ (Harriott et al. 1994). Approximately 90 coral species have been recorded from the Solitary Islands region, and their coral communities have a high cover of macroalgae and organisms more typical of temperate rocky reefs (Harriott et al. 1994). Lord Howe Island, about $600 \mathrm{~km}$ off the eastern Australian coast, is the southernmost true coral reef in the Pacific. About 80 coral species have been recorded from Lord Howe Island, and the community structure of reefs there has been described by Veron \& Done (1979) and Harriott et al. (1995). Racks were located on the western edge of the lagoon, in approximately 5 to $8 \mathrm{~m}$ water depth (Harriott 1992).

On retrieval, panels were bleached to remove noncalcareous biota. The lower (unglazed) surface was examined under a stereo microscope for the presence of coral recruits and various calcareous space-occupying taxa, including Bryozoa, Mollusca (vermetid gastropods and oysters), serpulid and spirorbid Polychaeta and barnacles. The bleaching process removed noncalcareous algae and soft-bodied organisms such as ascidians, sponges and hydroids. These taxa were not a significant component of cover on the lower surfaces of settlement panels at any site apart from the Solitary Islands, where further long-term studies including all taxa in the fouling community are in progress

For species abundance and taxonomic diversity data, all calcareous fauna were counted on each panel, using a dissecting microscope. Colonies of Bryozoa were separated at species level in most cases. The nonbryozoan animals such as corals and serpulids were generally identified at family level or higher. These taxa mostly consisted of 1 or a very few species each, however, so the loss of taxonomic resolution was not great. The Shannon-Wiener species-diversity index was calculated for each panel.

For the analysis of cover, each panel was photographed and the colour transparency examined under a 100-point random grid (Bohnsack 1979) to determine percentage cover of each calcareous taxon. The images of organisms on panels were grouped into 9 categories: Bryozoa, calcareous algae, spirorbid and serpulid Polychaeta, corals, barnacles, dead barnacle bases, oysters and bare panel surface. The taxonomic resolution for panel-cover estimation was thus coarser than for the microscopic examination of panel biota.

Community structure was examined by multivariate cluster analyses and ordination of species abundance and cover data. For abundance data, all species with a mean of less than 1 specimen per panel in any site/ season combination were excluded. The multivariate cluster analyses were based on Bray-Curtis similarities (Clarke \& Green 1988, Clarke 1993) and used fourthroot data transformations to control the level of influence of rare species (Clarke 1993). These analyses were followed by non-metric multidimensional scaling ordination (MDS; Kruskal \& Wish 1978, Clarke \& Green 1988) to provide additional information on the nature of site/time groupings. Contributions of separate taxa to the dissimilarity patterns of species abundances and panel cover between sites were examined using the similarity percentage analysis (SIMPER) procedure of Clarke (1993). Multivariate analyses and associated test procedures were carried out using the PRIMER software package (Plymouth Marine Laboratories, UK).

Weight of calcified material on each panel was determined by hydrochloric acid treatment of dried and preweighed panels, followed by rinsing in distilled water, drying to constant weight and final weighing Blank control panels were similarly treated to determine correction factors for loss of weight from the acidtreated ceramic material. Corrected weight losses of experimental panels were standardised to provide calcification values per month over the periods of exposure at each site and season.

Results for calcification rate of panels were analysed using 2-factor (site and season) ANOVA. Data for calcification rates were fourth-root transformed to normalise the data and homogenise variances across site/ times (confirmed by the use of Bartlett's test; Snedecor \& Cochran 1967). A posteriori pairwise comparisons of means were carried out using the Tukey HSD procedure (Winer 1971), selected following the critique of Day \& Quinn (1989).

\section{RESULTS}

\section{Species richness and diversity}

A total of 81 bryozoan species and 13 other taxa was found over the entire study. Of the 81 bryozoan species, 45 were relatively rare, appearing on 3 or fewer of the 103 panels surveyed, while 3 bryozoan species 
Table 1. Species richness and Shannon $H^{\prime}$ diversity of bryozoa and other taxa with site and season

\begin{tabular}{|c|c|c|c|c|c|c|c|c|}
\hline \multirow[t]{3}{*}{ Site } & \multirow{2}{*}{\multicolumn{2}{|c|}{$\begin{array}{c}\text { All samples } \\
\text { Species mchness }\end{array}$}} & \multicolumn{3}{|c|}{ Winter } & \multicolumn{3}{|c|}{ Summer } \\
\hline & & & \multicolumn{2}{|c|}{ Species richness } & \multirow{2}{*}{$\begin{array}{l}\text { Shannon } H^{\prime} \\
\text { a All taxa }\end{array}$} & \multicolumn{2}{|c|}{ Species nchness } & \multirow{2}{*}{$\begin{array}{l}\text { Shannon } H \\
\text { a All taxa }\end{array}$} \\
\hline & Bryozoa & Other taxa & Bryozoa & Other taxa & & Bryozoa & Other taxa & \\
\hline Solitary Islands & 46 & 11 & 24 & 7 & 0.93 & 43 & 11 & 1.71 \\
\hline Cape Tribulation & 39 & 10 & 17 & 9 & 1.36 & 35 & 9 & 1.17 \\
\hline Green Island & 21 & 10 & 3 & 8 & 1.21 & 20 & 10 & 1.43 \\
\hline Lord Howe Island & 8 & 12 & 7 & 11 & 1.33 & 3 & 10 & 1.14 \\
\hline
\end{tabular}

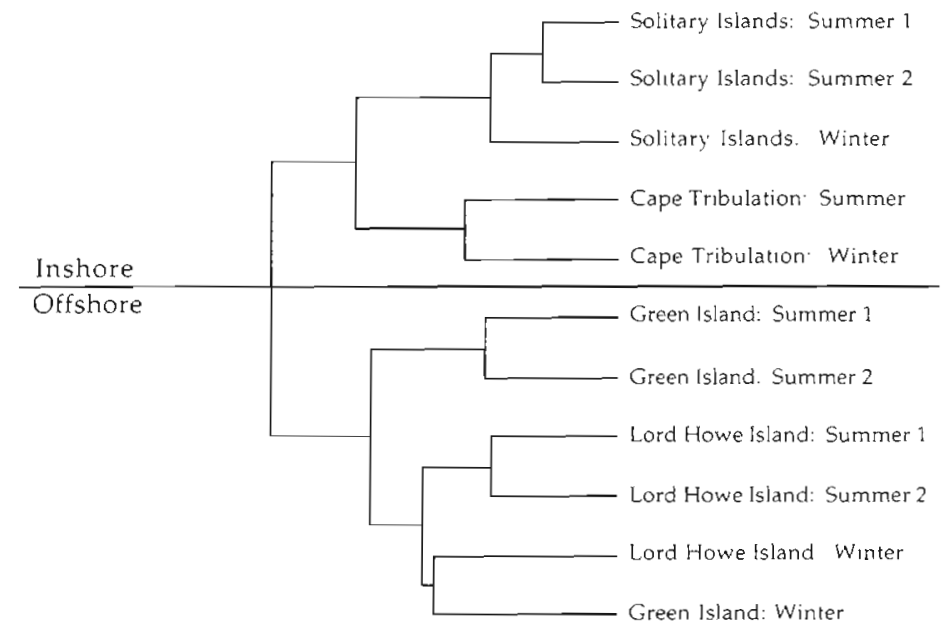

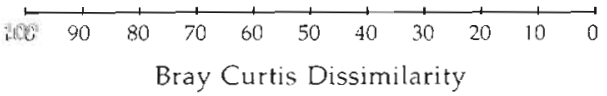

Fig. 2. Cluster analysis of sites/times in terms of species abundances on tiles. Note the marked inshore/offshore split

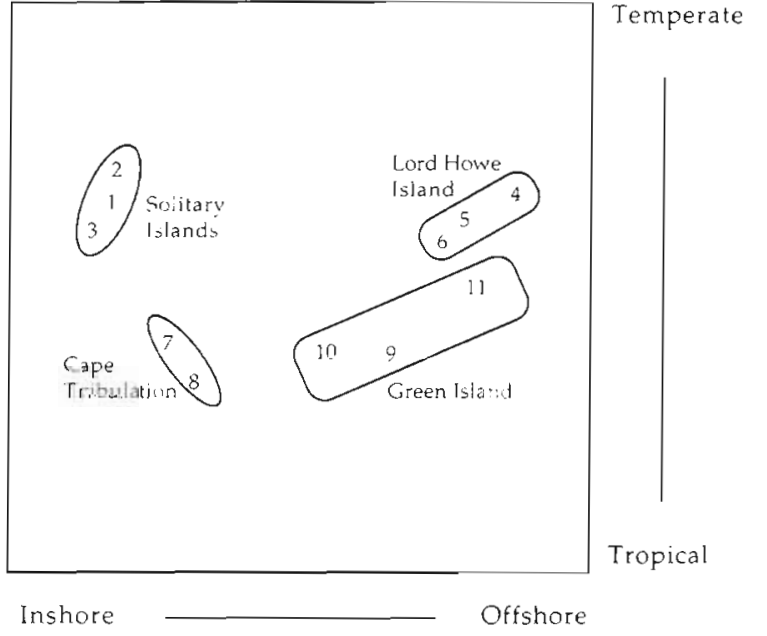

Fig. 3. MDS plot of sites/times in terms of species abundances on tiles.

1.2. Solitary Islands summers

3 , Solitary Islands winter

4, 5, Lord Howe Island summers

6. Lord Howe Island winter
7. Cape Tribulation summer 8. Cape Tribulation winter 9,10, (ireen Island summers 11, Green Island winter
(Parasmittina cf. delicatula, Lichenopora sp. and Tubulipora sp.) were common to all 4 locations. Non-bryozoan animal groups included juvenile vermetid molluscs, oysters, 2 species of serpulids, spirorbids, 5 taxa of coral juveniles and barnacles. Calcareous (encrusting coralline) algae were present at all sites.

The greatest species richness (57 species from 26 panels) was recorded from the subtropical inshore site (Solitary Islands), followed by the tropical inshore site (Cape Tribulation; 49 species, 19 panels), tropical offshore (Green Island; 31 species, 30 panels), and the subtropical offshore site (Lord Howe Island; 20 species, 27 panels) (Table 1). At the Solitary Islands, mean species diversity $\left(H^{\prime}\right)$ in winter was about half the summer mean value (representing the lowest and highest values respectively), while at the other 3 sites, diversity varied little between sites or between the 2 seasons (Table 1 ).

\section{Community analyses}

For the abundance data, cluster analysis showed a clear separation between inshore and offshore sites (Fig 2). The 2 inshore sites (Cape Tribulation and Solitary Islands) were also well separated from each other, but the offshore sites (Green Island and Lord Howe Island) were less clearly distinguished. Multidimensional scaling of the data from these classifications (Fig 3) showed a clear separation between the 4 sites, except for the Green Island winter sample which was not clearly separated from the Lord Howe Island group.

The SIMPER (similarity percentage; Clarke 1993) analyses, which indicate the taxa contributing most to the inter-group differences in the cluster analyses (Table 2), showed that differences between the Solitary Islands fauna and the other sites were attributable to good representation of barnacles and 2 bryozoan species (Lichenopora sp. and Bryozoan sp. 15) at the former. site. Lord Howe Island was separated from other sites mainly because of poor representa- 


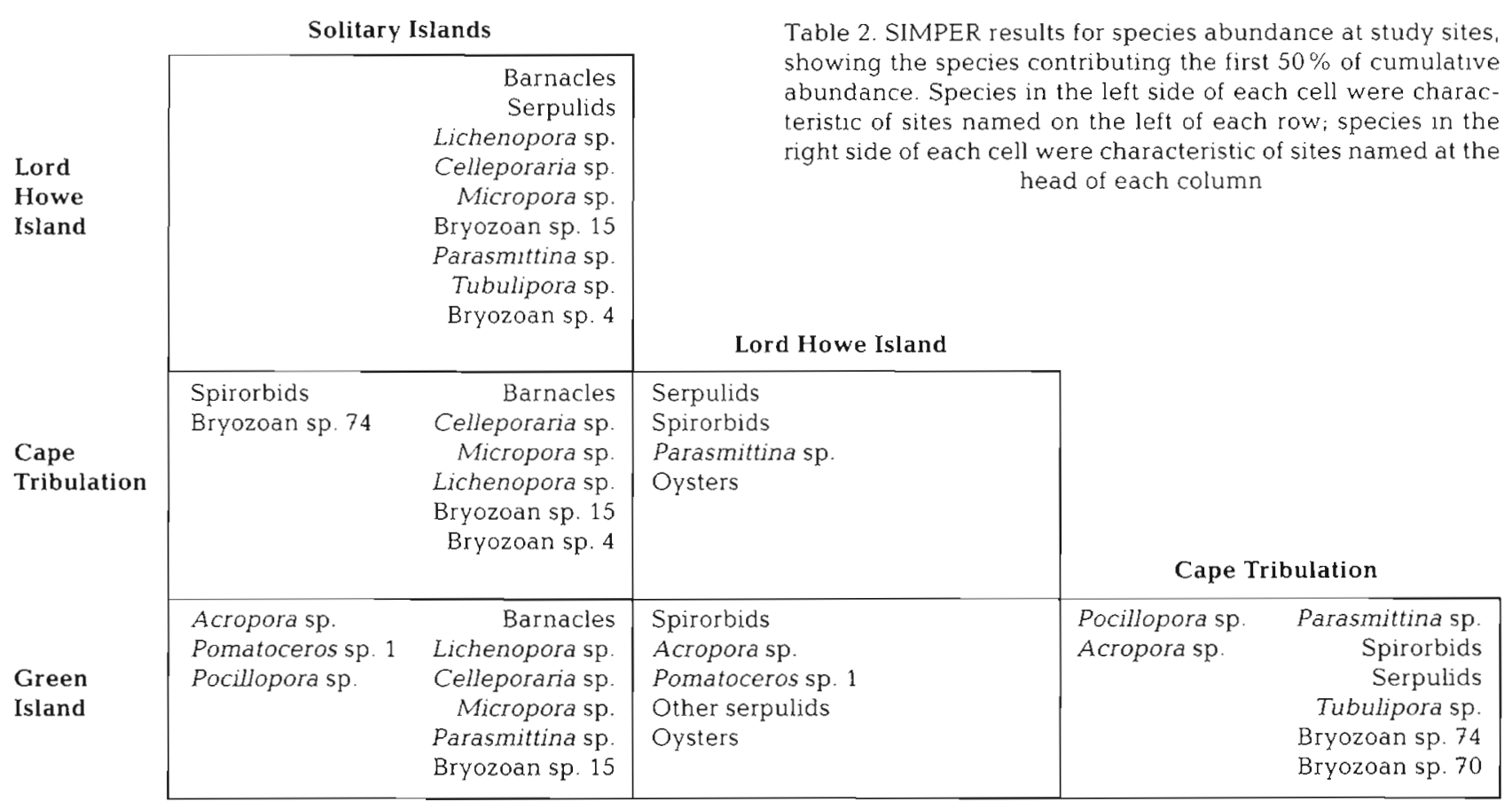

tion of all counted groups, reflecting the relatively low species richness at this site. Cape Tribulation had a relatively good representation of spirorbid and serpulid polychaetes, which separated it from the Solitary Islands. Green Island was separated from the Solitary Islands because of the presence of corals and a species of the polychaete Pomatoceros. Green Island was distinguished from Lord Howe Island by its representation of polychaetes, acroporid corals and oysters, and from Cape Tribulation by the greater abundance of pocilloporid corals at Green Island and of polychaetes, Tubulipora sp. and Parasmittina of. delicatula at Cape Tribulation.

In the results for panel cover (Table 3), cover for calcareous fauna was highest at the 2 inshore sites (44.2 to $71.5 \%$ at the Solitary Islands and 27.8 to $44.9 \%$ at Cape Tribulation), while cover of calcareous algae was highest at the 2 offshore sites (31.5 to $86.3 \%$ at Lord Howe Island and 31.3 to $67.0 \%$ at Green Island). At the Solitary Islands, bryozoans were the dominant cover, followed by barnacles and calcareous algae. At Cape Tribulation, bryozoa were dominant, followed by cal-

Table 3. Mean percentage cover on panels for 9 image categories at study sites

\begin{tabular}{|c|c|c|c|c|c|c|c|c|c|}
\hline & $\begin{array}{c}\text { Calcareous } \\
\text { algae }\end{array}$ & Bryozoa & Spirorbid & Serpulids & Corals & Barnacles & $\begin{array}{c}\text { Barnacle } \\
\text { bases }\end{array}$ & Oyster & $\begin{array}{r}\text { Total } \\
\text { fauna }\end{array}$ \\
\hline \multicolumn{10}{|l|}{ Solitary Islands } \\
\hline Summer 1990-91 & 9.9 & 58.2 & 0.2 & 1.4 & 0.1 & 11.1 & 0.3 & 0.4 & 71.5 \\
\hline Summer 1991-92 & 12.8 & 21.9 & 2.2 & 3.2 & 0.1 & 15.5 & 0.9 & 0.4 & 44.2 \\
\hline Winter 1991 & 19.5 & 30.1 & 0.2 & 4.4 & 0 & 22.1 & 0.6 & 0.1 & 57.5 \\
\hline \multicolumn{10}{|l|}{ Cape Tribulation } \\
\hline Summer 1987-88 & 13.5 & 25.5 & 6.2 & 12.4 & 0.2 & 0 & 0 & 0.6 & 44.9 \\
\hline Winter 1987 & 14.2 & 24.8 & 1.4 & 1.2 & 0 & 0 & 0 & 0.4 & 27.8 \\
\hline \multicolumn{10}{|l|}{ Green Island } \\
\hline Summer 1986-87 & 46.4 & 0.3 & 0.9 & 8.6 & 0.3 & 0 & 0 & 4.5 & 14.6 \\
\hline Summer 1987-88 & 31.3 & 4.5 & 1.3 & 6.3 & 0.6 & 0 & 0 & 2.5 & 15.2 \\
\hline Winter 1988 & 67.0 & 1.0 & 0.4 & 0.9 & 0.1 & 0 & 0 & 0.6 & 3.0 \\
\hline \multicolumn{10}{|l|}{ Lord Howe Island } \\
\hline Summer 1990-91 & 55.9 & 0.4 & 0 & 0.14 & 0.7 & 0 & 0 & 0.1 & 1.34 \\
\hline Summer 1991-92 & 31.5 & 0.3 & 0.3 & 0.13 & 1.1 & 0 & 0.1 & 0.2 & 2.13 \\
\hline Winter 1991 & 86.3 & 2.7 & 0.3 & 1.0 & 0.1 & 0 & 0 & 0.3 & 4.4 \\
\hline
\end{tabular}




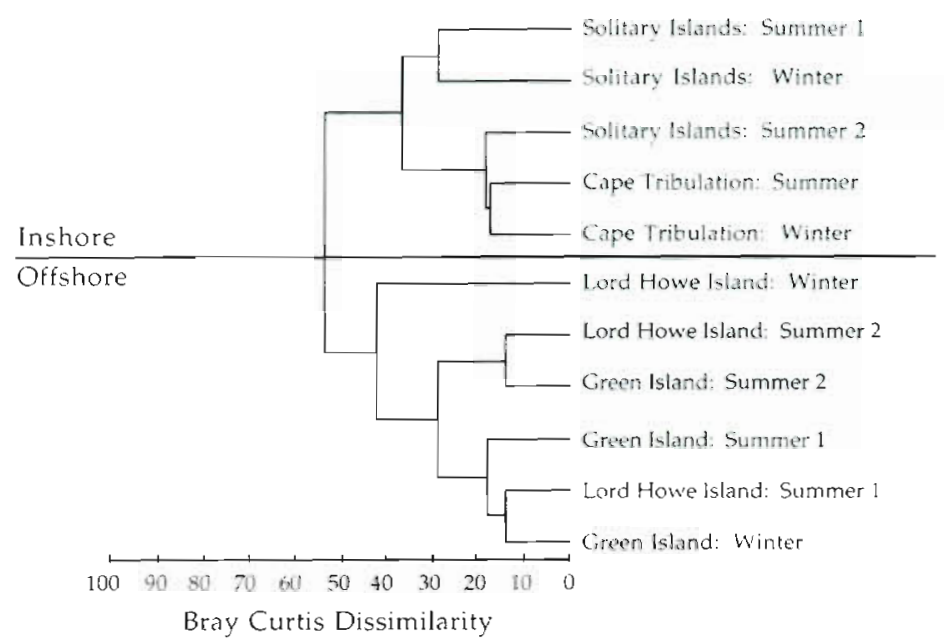

Fig. 4. Cluster analysis of sites/tumes in terms of tile cover of 9 image categones. Note inshore/offshore split.

careous algae and serpulids. At Green Island and Lord Howe Island, calcareous algae formed the dominant category, with serpulids at Green Island the only other category contributing more than 5\% cover (Table 3 ).

Multivariate cluster analyses of panel-cover data showed a clear distinction between inshore and offshore site/season groups (Fig. 4), similar to the results for taxonomic abundance. However, the classification did not clearly distinguish between sites within the offshore and inshore groups (Fig. 4), indicating that the broader level of taxonomic resolution for the cover analysis less clearly distinguishes sites from each other.

\section{Calcification rates}

The results of 2-way ANOVA of calcification by site and season showed significant effects of site and season on calcification rate of panels (site: $F=67.5, \mathrm{df}=3$,

Table 4. Results of Tukey HSD a posterior comparisons of calcification rates (mean seasonal calcification, untransformed data, $\mathrm{g}$ tile $\mathrm{mo}^{-1}$ ) at site/season combinatıons. Significance groupings of site/season combinations are separated

\begin{tabular}{|lcc|}
\hline Site/season & No. of panels & Calcification \\
\hline Solutary Islands, winter & 8 & 1.155 \\
Solitary Islands, summers & 18 & 1.149 \\
Green Island, winter & 10 & 0.819 \\
Green Island, summers & 20 & 0.708 \\
Lord Howe Island, winter & 11 & 0.690 \\
Cape Tribulation, winter & 9 & 0.666 \\
Lord Howe Island, summers & 8 & 0.564 \\
Cape Tribulation, summer & 11 & 0.547 \\
\hline
\end{tabular}

$\mathrm{p}=0.0001$, season: $F=8.74, \mathrm{df}=1, \mathrm{p}=0.004)$, with no significant interaction between factors $(F=0.87, \mathrm{df}=3, \mathrm{p}=0.46)$. A posteriori comparisons of the means (Tukey HSD) showed that the Solitary Islands mean calcification weights were significantly higher than those at the other 3 sites, which formed a coherent group (Table 4). On the basis of taxa contributing to panel cover (Table 3) the major contributors to calcification rates appear to be Bryozoa, barnacles and calcareous algae at the Solitary Islands, Bryozod and calcareous algae at Cape Tribulation and calcareous algae at Green and Lord Howe Islands

\section{DISCUSSION}

\section{Species richness}

The abundant taxa in this study are typical of those reported in other studies of fouling communities in eastern Australia. Bryozoans made the greatest contribution to species richness at the Solitary Islands, Green Island and Cape Tribulation, representing 68 to $81 \%$ of taxa recorded at these sites. At Lord Howe Island, overall species richness was lower and bryozoans represented $44 \%$ of species. In other studies of fouling communities in eastern Australia, Allen \& Ferguson Wood (1950) recorded a total of 30 bryozoan species, which formed a large proportion of the growth on most panels at several sites on the Australian east coast. Wisely (1959) reported that the dominant organisms in Sydney Harbour $\left(33^{\circ} 50^{\prime}\right.$ S) comprised barnacles, tubeworms, bryozoans and bivalve molluscs. Moran \& Grant (1989) found that fouling communities at. Wollongong $\left(34^{\circ} 27^{\prime} \mathrm{S}\right)$ included 21 bryozoan species, and 15 other calcareous species, including bivalves, barnacles and polychaetes. Holmes (1982) found 33 species of Bryozoa on panels of 6 to $48 \mathrm{wk}$ exposure in Port Phillip Bay, Victoria $\left(37^{\circ} 51^{\prime} \mathrm{S}\right)$, but the dominant calcareous forms on $6 \mathrm{wk}$ spring and summer panels were barnacles and serpulid worms.

The species richness of bryozoans recorded in this study was generally higher than the total of 12 species reported by Schoener \& Schoener (1981) from Puget Sound (USA) and the 15 species recorded by Winston \& Jackson (1984) on panels submerged for up to $3 \mathrm{yr}$ in Jamaica. Schoener et al. (1978) reported up to 12 species of calcareous forms and algae, hydroids and ascidians on 6 mo panels in subtropical and tropical sites. They also noted that in both Thailand and Hawaii calcareous organisms predominated on their panels.

The high abundances of calcareous forms and the importance of bryozoans found in the present study thus reflect the findings from panel studies elsewhere. 
It appears, however, that the species richness of Bryozoa found on our panels, especially at the inshore sites, far exceeds that reported by other workers. Ryland (1974) noted that the Indo-Pacific region appeared to support more bryozoan species than the Caribbean. However, Kobluk et al. (1988) reported 75 species of bryozoans from cryptic reef habitats in the Caribbean, indicating that the Bryozoa are a diverse component of reef faunas. Choi \& Ginsburg (1981, 1983) found marked zonation of cryptic faunas (including 29 species of Bryozoa) on a scale of about $10 \mathrm{~km}$ across the Florida Reef Tract in Biscayne Bay (USA).

\section{Inshore versus offshore sites}

Spatial variations in community structure may result from interactions among (1) geographical distributions of breeding stocks of various taxa and the timing of breeding, (2) larval transport mechanisms, e.g ocean and coastal currents (Roughgarden et al. 1987), (3) variations in water quality factors, e.g. turbidity and nutrients, and their effect on larval settlement (Schmidt 1982) and survival. All of these factors may vary along both latitudinal and inshore/offshore gradients and, in addition, small-scale factors (e.g. of habitat distribution in an area, see Choi \& Ginsburg 1983) may distort or locally reverse a larger-scale trend.

In the present study the differences in panel biota between inshore and offshore sites were much greater than differences over a much larger latitudinal distance, e.g. fouling communities at Green Island were inseparable in some analyses from those at Lord Howe Island over $1600 \mathrm{~km}$ to the south and well off the edge of the continental shelf, but were clearly distinct from those at Cape Tribulation less than $100 \mathrm{~km}$ away. Inshore panels were more species-rich than offshore panels at a similar latitude, with the highest richness found at the subtropical inshore site. This pattern may reflect species representation in nearby cryptic habitats as well as larger-scale gradients in the distributions of communities

On the Great Barrier Reef several studies have examined cross-shelf differences in coral reef communities (e.g. Done 1982, Williams et al. 1984). The gradient from more turbid, physically variable and nutrientrich inshore waters to clear oligotrophic offshore water was reflected in significant variation in community structure for most taxa (Wilkinson \& Cheshire 1989). Dinesen (1983) found that soft coral diversity increased with distance offshore in the central Great Barrier Reef and Sammarco (1983) found a broadly similar pattern for coral recruits. It has been suggested (e.g. Williams et al. 1984) that strong connections by long-shore currents due to the dominance of the East Australian Cur- rent may inhibit cross-shelf transport, which would lead to cross-shelf variation in the suites of species available to settle. Farrell et al. (1991) showed that recruitment of coastal barnacles in California (USA) was affected by cross-shelf currents altered by changes in wind patterns, indicating that mesoscale water movements may exert a significant influence on larval supply.

Hughes \& Jackson (1992) examined spatial patterns in the distribution of cryptic cheilostome bryozoans on the undersurfaces of coral colonies at 8 sites in and near the Caribbean coast of Panama. They reported higher cover of bryozoans at offshore sites than at mainland sites (the reverse of our findings), but no consistent pattern of species diversity. They concluded that exposure to mainland run-off was not a major determinant of bryozoan community structure in that area and that the effects of local topography on environmental heterogeneity (and, by implication, the distribution of cryptic habitats) may be more important.

Long \& Rucker (1970), however, reported fewer bryozoan species on offshore settlement panels in Florida. They concluded that rate of colonisation was limited by the dispersal distance of larvae rather than the presence of unsuitable environmental conditions. These findings, also, suggest that local cryptic habitat distribution and its effects on larval supply may have important influences on panel biotas.

Calcareous algae were the dominant space-occupiers at the offshore sites at Green Island and Lord Howe Island, with propagules presumably derived from nearby habitats. The relatively low cover of calcareous algae at the inshore sites (Cape Tribulation and the Solitary Islands) might be attributable to low light levels in the more turbid coastal waters, to space pre-emption by other species or to lack of nearby breeding populations able to supply propagules to the panel sites, but there are insufficient data to evaluate these conjectures.

\section{Latitudinal differences}

In the present study, latitudinal variation in species richness and community structure was less significant than cross-shelf differences. There was no consistent trend with latitude for species richness or diversity, with both the highest and lowest species richness and diversity found at the high latitude sites.

Latitudinal variations in marine species diversity and community structure have recently been discussed by Schoener et al. (1978), Black \& Prince (1983), Crossland (1988), Keough (1988), McGuinness (1990), Clarke (1992) and other authors. Tropical habitats are commonly assumed to have a higher species richness 
than similar habitats in higher latitudes but Clarke (1992) notes that some groups, including bryozoans and polychaetes, are species-rich in high southern latitudes.

Consistent with the result of the present study, McGuinness (1990) compared diversity in high and low latitude marine environments and concluded that temperate communities were not always less diverse than those in the tropics, at least at small spatial scales. Black \& Prince (1983) examined patterns in species diversity in the fauna associated with heads of the coral Pocillopora damicornis at a number of sites at different latitudes and found a reduction in regional species richness in the high-latitude coral communities, but no clear pattern in the species diversity per unit sampled.

Schoener et al. (1978) concluded that initial colonisation rates on settlement panels were higher at tropical than at temperate sites, but that between 6 mo and 1 yr (when their study finished) the species richness of panels did not vary greatly with latitude. However, the overall species richness at each site was 2 to 3 times higher at their tropical and subtropical sites than at their temperate sites. They concluded that the greater species richness associated with tropical marine environments may be due to a greater variety of habitats present, rather than greater within-habitat diversity in the tropics.

In another comparison, Schoener \& Schoener (1981) and Greene et al. (1983) concluded that space was occupied much more slowly on fouling panels at Jackson's (1977b) tropical site than in their studies in Puget Sound. Schoener \& Schoener (1981) suggested that the contrast may reflect local habitat differences, a possibility supported by the lack of barnacles at Jackson's tropical site. However, comparison of the sites is complicated by the fact that Jackson's tropical study site was at 40 m depth, while the Schoeners' cool-temperate site was at about $1 \mathrm{~m}$ below water level in a site about $4 \mathrm{~m}$ deep, close to the shore.

In a separate study, Winston \& Jackson (1984) also reported that recruitment and growth of tropical bryozoans (at a shallower site, 12 to $13 \mathrm{~m}$, than that of Jackson 1977 b) in Jamaica was lower than at temperate sites. In plates submerged for 7 mo, cover of cheilostome bryozoans ranged from 0.8 to $2.1 \%$, and cover of calcareous algae ranged from zero to $0.4 \%$ The cover of bryozoans was comparable with those reported here for our 2 offshore sites at Green Island and Lord Howe Island (means of $1.9 \%$ and $1.1 \%$ respectively; Table 3), but was significantly lower than mean bryozoan cover at the 2 inshore sites (the Solitary Islands $36.7 \%$ and Cape Tribulation $25.1 \%$ ). At all our sites, mean cover of calcareous algae was much higher after 4 to $8 \mathrm{mo}$ ( 9.9 to $86.3 \%$; Table 3 ) than in Winston \& Jackson's (1984) study after the first 7 mo, though cover of calcareous algae on their $15 \mathrm{mo}$ old panels was 52.5 and $33.8 \%$ at depths of 10 and $22 \mathrm{~m}$ respectively (Jackson \& Winston 1982).

The higher species richness on subtropical than tropical panels at inshore sites found in our study thus appears to be broadly consistent with the findings of other studies. Bryozoans formed the major component of the Solitary Islands fauna and, since Ryland (1976) has noted that bryozoan larvae are usually brooded and have limited dispersal abilities, the high species richness at this site may reflect the presence of smallscale larval transport mechanisms bringing larvae from local subtidal habitats. In addition, the subtropical east coast of Australia contains a range of intertidal and subtidal rocky habitats, which may provide a high diversity of propagules on a subregional or smaller scale.

\section{Competition for settlement space}

In a study of coral recruitment in areas of upwelling in the Eastern Pacific, Birkeland (1977) concluded that successful coral recruitment was a rare event in upwelling areas because of competition for settlement space with other organisms such as barnacles, bryozoans, tunicates and algae which quickly monopolised space on artificial settlement surfaces. Johannes et al. (1983), in an evaluation of the factors limiting the distribution of coral reefs at high latitudes, hypothesised that the poleward distribution of corals might be limited by the inability of corals to compete successfully, both as larvae and as adults, with temperate biota

In the present study, the Solitary Islands panels had the highest cover of bryozoans, barnacles and other fauna, limiting the amount of free space on settlement panels submerged for approximately 4 mo. At the Solitary Islands, coral recruitment rates were lower than at the other 3 sites reported here (Harriott \& Banks 1995). The high rate of colonisation of non-coral calcareous organisms at the Solitary Islands relative to other sites indicates that competition for space with calcareous fouling organisms may be a major factor that might limit coral recruitment in coastal subtropical eastern Australia. Where cover is very high, allelopathic interactions are likely to play a highly significant role in structuring these cryptic communities (Dyrynda 1983, Rodriguez et al. 1993, Maida et al. 1995a, b)

\section{CaIcification rates}

The calcification rate of the fouling communities at the Solitary Islands was significantly higher than at the other 3 sites (Table 4 ), reflecting the findings for abun- 
dance and cover of calcareous organisms. Calcareous algae were important occupiers of panel space at all sites, but the Solitary Islands panels also supported a significant cover of bryozoans and barnacles, and the latter, especially, may have been important contributors to calcification at that site. Bryozoans have been found also to contribute significantly to calcification in warm temperate New Zealand (Smith \& Nelson 1994).

Johannes et al. (1983) report that total community calcification at a subtropical coral community in Western Australia was not depressed relative to tropical reefs, despite a reduction in coral growth rate at the same site. They suggested that other (non-coral) calcifying biota might contribute more to community calcification at the high latitude reef than at tropical reefs. The present data suggest that barnacles, Bryozoa and calcareous algae are capable of significant contributions to community calcification on subtropical reefs.

Acknowledgements. Thanks are due to Dr S. D. A. Smith for comments on an earlier draft of this paper, to Dr Phil Bock for assistance with identifying bryozoans, and to 2 anonymous reviewers for suggesting significant improvements to the manuscript. This project was funded by an Internal Research Grant from Southern Cross University.

\section{LITERATURE CITED}

Allen FE, Ferguson Wood EJ (1950) Investigations on underwater fouling. 1l. The biology of fouling in Australia results of a year's research. Aust J Mar Freshwat Res 2: $92-10$

Ayling TM, Ayling AL (1987) Is silt run-off affecting coral communities on Cape Tribulation fringing reefs? In: Baldwin CL (ed) Fringing Reef Workshop-Science, Industry and Management. Great Barrier Reef Marine Park Authority, Townsville, p 83-85

Benayahu Y, Loya Y (1984) Substratum preferences and planulae settling of two Red Sea alcyonaceans: Xenia macrospiculata Gohar and Parerythropodium fulvum fulvum (Forskal). J Exp Mar Biol Ecol 83:249-261

Bingham BL (1992) Life histories in an epifaunal community: coupling of adult and larval processes. Ecology 73: $2244-2259$

Birkeland C (1977) The importance of rate of bromass accumulation in early successional stages of benthic communities to the survival of coral recruits. Proc 3rd Int Coral Reef Symp 1:15-21

Black KP (1988) The relationship of reef hydrodynamics to variations in numbers of planktonic larvae on and around coral reefs. Proc 6th Int Coral Reef Symp 2:125-130

Black R, Prince J (1983) Fauna associated with Pocillopora damicornis at the southern limit of its distribution in Western Australia. J Biogeogr 10:135-152

Bohnsack JA (1979) Photographic quantitative sampling of hard-bottom benthic communities. Bull Mar Sci 29 $242-252$

Breitburg DL (1984) Residual effects of grazing: inhibition of competitor recruitment by encrusting coralline algae. Ecology 64:1136-1143

Carleton JH, Sammarco PW (1987) Effects of substratum irregularity on success of coral settlement: quantification by comparative geomorphological techniques. Bull Mar Sci 40:85-98

Carlon DB, Olson RR (1993) Larval dispersal distance as an explanation for adult spatial pattern in two Carbbean reef corals. J Exp Mar Biol Ecol 173:247-263

Chol DR, Ginsburg RN (1981) Distrubution and succession of coelobites (cavity-dwellers) in coral rubble across the northern Flonda reef tract. Proc 4 th Int Coral Reef Symp $2: 781$

Chol DR, Ginsburg RN (1983) Distribution of coelobites (cavity-dwellers) in coral rubble across the Florida reef tract. Coral Reefs 2:165-172

Clarke A (1992) Is there a latitudinal diversity cline in the sea? Trends Ecol Evol 7:86-87

Clarke KR (1993) Non-parametric multivariate analyses of changes in community structure. Aust J Ecol 18:117-143

Clarke KR, Green RH (1988) Statistical design and analysis for a 'biological effects' study. Mar Ecol Prog Ser 46 : $213-226$

Connell JH, Keough MJ (1985) Disturbance and patch dynamics of subtidal marine animals on hard substrata. In: Pickett STA, White PS (eds) The ecology of natural disturbance and patch dynamics. Academic Press, London, p $125-151$

Crossiand CJ (1988) Latitudanal comparisons of coral reef structure and function. Proc 6th Int Coral Reef Symp 1: $221-226$

Day RW, Quinn GP (1989) Comparısons of treatments after an analysis of variance in ecology. Ecol Monogr 59:433-463

Dayton PK (1971) Competition, disturbance and community organization: the provision and subsequent utilization of space in a rocky intertidal community. Ecol Monogr 41: $351-389$

Dinesen ZD (1983) Patterns in the distribution of soft corals across the central Great Barrier Reef. Coral Reefs 1: 229-236

Done TJ (1982) Patterns in the distribution of coral communities across the central Great Barrier Reef. Coral Reefs 1 : 95-107

Dyrynda PEJ (1983) Modular sessile invertebrates contain larvotoxic allelochemicals. Dev Comp Immunol 7:621-624

Farrell TM, Bracher D, Roughgarden J (1991) Cross-shelf transport causes recruitment to intertidal populations in central California. Limnol Oceanogr 36:279-288

Fisk DA, Harriott VJ (1990) Spatial and temporal variation in coral recruitment on the Great Barrier Reef: implications for dispersal hypotheses. Mar Biol 107:485-490

Fisk DA, Harriott VJ, Pearson RG (1989) The history and status of crown-of-thorns starfish and corals at Green lsland Reef. Proc 6th Int Coral Reef Symp 2:149-155

Gunsburg RN (1983) Geological and biological roles of cavities in coral reefs. In: Barnes DJ (ed) Perspectives on coral reefs. Brian Clouston, Canberra, p 148-153

Gischler E, Ginsburg RN (1996) Cavity dwellers (coelobites) under coral rubble in southern Belize barrier and atoll reefs. Bull Mar Sci 58:570-589

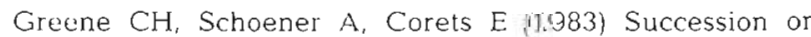
marine hard substrata: the adaptive significance of solitary and colonial strategies in temperate fouling communities. Mar Ecol Prog Ser 13:121-129

Harriott VJ (1992) Recruitment patterns of scleractinian corals in an isolated sub-tropical reef system. Coral Reefs 11: $215-219$

Harriott VJ, Banks SA (1995) Recruitment of scleractinian corals in the Solitary Islands Marine Reserve, a high latitude coral-dominated community in Eastern Australia. Mar Ecol Prog Ser 123:155-161 
Harriott VJ, Harrison PL, Banks SA (1995) The coral communities of Lord Howe Island. Nar Freshwat Res 46:457-465

Harriott VJ, Smith SDA, Harrison PL (1994) Patterns of coral community structure of subtropical reets in the Solitary Islands Marine Reserve, Eastern Australia. Mar Ecol Prog Ser 109:67-76

Harris LG, Irons KP (1982) Substrate angle and predation as determinants in foulnng community succession. In: Cairns J (ed) Artificial substrates. Ann Arbor Science Publ, Ann Arbor, MI, p 131-174

Holmes N (1982) Scientific report of the epibiotic panel study. In: Sandiford RN, Holmes $N$ (eds) The heated effluent study for Victorian coastal waters: final report and supplementary scientific papers. Marine Science Laboratories Tech Rep 15. Ministry for Conservation, Victoria, p 87-172

Hughes DJ, Jackson JBC (1992) Distribution and abundance of cheilostome bryozoans on the Caribbean Reefs of Central Panama. Bull Mar Scl 51:443-465

Jackson JBC (1977a) Habitat area, colonisation and development of epibenthic community structure. In: Keegan BF, Ceidigh PO, Boaden PJS (eds) Biology of benthic organisms. Pergamon, Oxford, p 349-358

Jackson JBC (1977b) Competition on marine hard substrata: the adaptive significance of solitary and colonial strategies. Am Nat 111:743-767

Jackson JBC, Winston JE (1982) Ecology of cryptic coral reef communities. I. Distribution and abundance of major groups of encrustıng organisms. J Exp Mar Biol Ecol 57: $135-147$

Johannes RE, Wiebe WJ, Crossland CJ, Rimmer DW. Smith SV (1983) Latitudinal limits of coral reef growth. Mar Ecol Prog Ser 11:105-111

Keough MJ (1988) Benthic populations: is recruitment limiting or just fashionable? Proc 6th Int Coral Reef Symp 1. $141-148$

Keough MJ. Downes BJ (1982) Recruitment of marine invertebrates: the role of active larval choice and early mortality. Oecologia 54:348-352

Kobluk DR, Cuffey RJ, Fonda SS, Lysenko MA (1988) Cryptic Bryozoa, leeward fringing reef of Bonaire, Netherlands Antilles, and their paleoecological implications. J Paleontol 62:427-439

Kruskal JB, Wish M (1978) Multidimensional scaling. Sage Publications, Newbury Park, CA

Long ER, Rucker JB (1970) Offshore marine chellostome Bryozoa from Fort Lauderdale, Florida. Mar Biol 6:18-25

Maida M, Sammarco PW, Coll JC (1995a) Preliminary ev1dence for directional allelopathic effects of the soft coral Sinuaria flexibllis (Alcyonacea: Octocorallia) on scleractinian coral recruitment. Bull Mar Sci 56:303-311

Maida M, Sammarco PW, Coll JC (1995b) Effects of soft corals on scleractinian coral recruitment. T. Directional alleopathy and inhibition of settlement. Mar Ecol Prog Ser 121:191-202

McGuinness KA (1990) Physical variability, diversity gradients and the ecology of temperate and tropical reefs. Aust $J$ Ecol 15:465-476

Moran PJ, Grant TR (1989) The effects of industrial pollution on the development and succession of marine fouling communities. I. Analysis of species richness and frequency data. PSZN I: Mar Ecol 10:231-246

Patzkowsky ME (1988) Differential response of settling larvae to resident colony density in two species of Bugula (Bryozoa: Cheilostomata). J Exp Mar Biol Ecol 124:57-63

Rodriguez SR, Ojeda FP, Inestrosa NC (1993) Settlement of benthic marne invertebrates. Mar Ecol Prog Ser 97 $193-207$
Roughgarden J, Gaines SD, Pacala SW (1987) Supply side ecology: the role of physical transport processes. In: Gee $J H R$, Giller PS (eds) Organization of communities past and present. Blackwell, Oxford, p 491-518

Russ GR (1982) Overgrowth in a marine epifaunal community: competitive hierarchıes anc networks. Oecologia 53 $12-19$

Rylaarsdam K (1983) Life histories and abundance patterns of colonaal corals on Jamaican reefs. Mar Ecol Prog Ser 13 $249-260$

Ryland JS (1974) Bryozoa in the Great Barrier Reef province Proc 2nd Int Symp Coral Reefs 1:341-348

Ryland JS (1976) Physlology and ecology of marine bryozoans. Adv Mar Biol 14:285-443

Sammarco PW (1983) Coral recruitment across the central Great Barner Reef: a prelminary report. In: Baker JT Carter RM. Sammarco PW, Stark KP (eds) Proc Inaug Great Barrier Reef Conf, Townsville, Qld. James Cook University, Townsville, p 245-250

Sammarco PW, Andrews JC (1989) The Helix experiment: differential localized dispersal and recruitment patterns in Great Barrier Reef corals. Limnol Oceanogr 34:896-912

Sammarco PW, Andrews JC, Risk MJ (1991) Coral reef geomorphology as a function of seasonal prevailing currents and larval dispersal. Palaeogeogr Palaeoclimatol Palaeoecol 88:1-12

Schmidt GH (1982) Random and aggregative settlement in some sessile marine invertebrates. Mar Ecol Prog Ser 9: $97-100$

Schoener A (1982) Artificial substrates in marune environments. In: Cairns J (ed) Artificial substrates. Ann Arbor Science Publ, Ann Arbor, MI, p 1-22

Schoener A, Long ER, DePalma JR (1978) Geographic variation in artificial island colonisation curves. Ecology 59 : $367-382$

Schoener A, Schoener TW (1981) The dynamics of the specles-area relation in marine fouling systems: 1 Biological correlates of changes in the species-area slope. Am Nat $118 \cdot 339-360$

Sebens KP (1983) Settlement and metamorphosis of a temperate soft-coral larva (Alcyonium siderium Verrill): induction by crustose coralline algae. Biol Bull Mar Biol Lab Woods Hole 165:286-304

Smith AM, Nelson CS (1994) Calcification rates of rapidly colonizing bryozoans in Haurakı Gulf, northern New Zealand. NZ J Mar Freshwat Res 28:227-234

Smith SR (1992) Patterns of coral recruitment and post-settlement mortality on Bermuda's reefs: comparisons to Carıbean and Pacific reefs. Am Zool 32:663-673

Snedecor GW, Cochran WG (1967) Statistical methods, 6th edn. Iowa State University Press, Ames

Standing JD, Hooper JR, Costlow JD (1984) Inhibition and induction of barnacle settlement by ndtural products present in octocorals. J Chem Ecol 10:823-834

Sutherland JP (1974) Multiple stable points in natural communties. Am Nat 108:859-873

Underwood AJ, Fairweather PG (1989) Supply side ecology and benthic marine assemblages. Trends Ecol Evol 4:16-20

van Moorsel GWNM (1988) Early maximum growth of stony corals (Scleractinia) after settlement on artifical substrata on a Caribbean reef. Mar Ecol Prog Ser 50:127-135

Veron JEN, Done TJ (1979) Coral communities of Lord Howe Island. Aust J Mar Freshwat Res 30:203-236

Wallace CC (1985) Seasonal peaks and annual fluctuations in recruitment of juvenile scleractinian corals. Mar Ecol Prog Ser 21:289-298

Wilkınson CR, Cheshire AC (1989) Cross-shelf variatıons in 
coral reef structure and function-influences of land and ocean. Proc 6th Int Coral Reef Symp 1:227-233

Williams DMcB, Wolanski E. Andrews JC (1984) Transport mechanisms and the potential of planktonic larvae in the central region of the Great Barner Reef Coral Reefs 3: $229-236$

Winer BJ (1971) Statistical principles in expermental design, 2nd edn. McGraw-Hill Kogakusha, Tokyo

Winston JE, Jackson JBC (1984) Ecology of cryptic coral reef

This article was submitted to the editor communities. IV. Community development and life hıstories of encrusting cheilostome Bryozoa. J Exp Mar Biol Ecol 76:1-21

Wisely $B(1959)$ Factors influencing the settling of the principal marine fouling organisms in Sydney Harbour. Aust $J$ Mar Freshwat Res 10:30-44

Young CM (1988) Larval predation by barnacles: effects on patch colonization in a shallow subtıdal community. Ecology 69:624-634

Manuscript received: April 16, 1997

Revised version accepted: June 18, 1997 